\title{
Beware of false profits
}

\section{Academics must consider the true cost of dealings with the marketplace.}

\section{Universities in the Marketplace: The Commercialization of Higher Education \\ by Derek Bok \\ Princeton University Press: 2003. 256 pp.

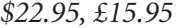 \\ Jeremy Gunawardena}

The president of a leading university uses a US\$2-billion loan to attract "worldrenowned scholars, dazzling new buildings, incredibly talented students". The president is fêted as an innovative academic leader, but the inexorable demands for repayment of the loan begin a steady process of decline. The athletic programme is refurbished to raise lucrative television income. The university museum is forced to divest itself of its treasures. The rights to exploit the university's biological research are sold to a pharmaceutical company. A for-profit Internet venture is launched selling degrees to students worldwide. Advertisements are placed in classrooms, and company logos appear on course material. Finally, in desperation, 100 undergraduate places are auctioned to the highest bidder.

This not-so-hypothetical nightmare must have surprised the audience at Harvard University's 1988 commencement when Harvard's then president, Derek Bok, recounted it to drive home his concern about the perils of commercialization. The nightmare has continued to haunt him, and he returns to it in this humane and beautifully crafted book. Bok believes that the intrusion of the marketplace into the university is eroding fundamental academic values, and that we must act now to halt this decline.

The universities and marketplace discussed by Bok are American, and he has nothing to say about the very different histories and contexts elsewhere. But readers who are puzzled by the attention given to university sports, a peculiarly American obsession, will find much here that is of universal interest.

Corporate sponsorship of research is a concern for many readers of Nature. Bok recounts the cases of two researchers whose attempts to publish the results of negative clinical trials elicited ugly harassment from the drug companies involved but little support from their respective institutions. Such egregious examples at least attract considerable attention. The subtle, and sometimes not so subtle, effects of distortion and undue influence are much more damaging when they are largely invisible. A survey of academic studies on the effects of passive smoking found that, of the investigators with ties to the tobacco industry, $94 \%$ claimed that it is not

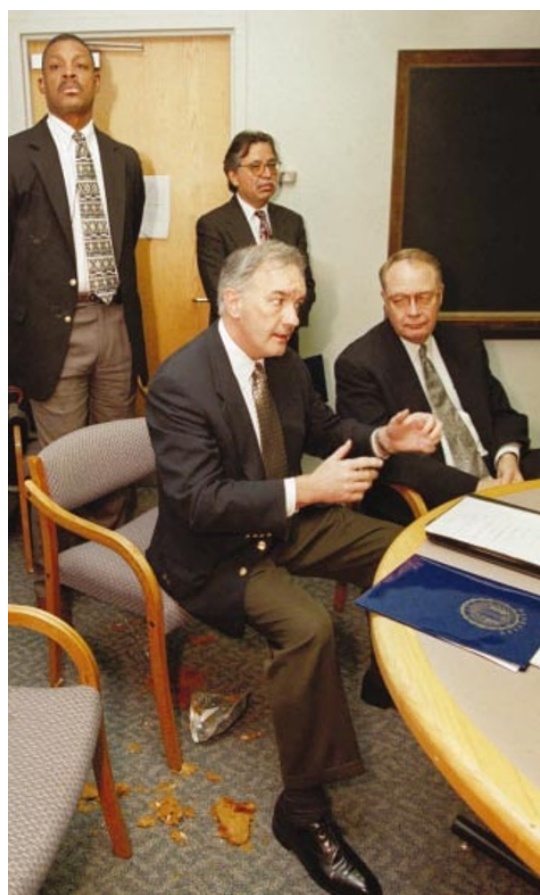

Crust under foot? Protesters failed to stop Novartis president Douglas Watson giving \$25 million to the University of California, Berkeley.

harmful, whereas $87 \%$ of those without such ties claimed that it is. Conflicts of interest that would be considered scandalous in public life elicit little comment, until some unfortunate incident attracts public attention.

As Bok argues, the remedy for such ills is to enforce full disclosure of all forms of sponsorship. It is troubling that such an obvious suggestion, so consistent with academic values, has not already been implemented by more universities and journals (Nature adopted such a policy in 2001; see Nature 412 , 751). Are some academics concerned that the uninformed public may draw the 'wrong' conclusions from such revelations? If so, the public will eventually draw the right conclusions about such academics.

The commercialization of teaching raises a different set of issues. Bok recognizes the potential of the Internet to enrich the learning experience, in the face of the faculty's resistance to change (a deeply cherished 'academic value'). As Bok once said: "I fully intend to break my lance, as presidents have before me, against the wall of better teaching." Here he attempts to balance the wall-breaking potential against the dangers of selling poorquality courses to ill-informed students for a quick, and probably illusory, profit.

It is a difficult balancing act throughout. The graceful language and judicious argu- ments do not conceal the leaps that Bok has to take in navigating across this ethical quagmire. Private universities charge fees. Business and medical schools run their professional programmes as lucrative, profitmaking enterprises. The money may not go into shareholder's pockets, but that may be of little comfort to those who pay. If commercial companies insist on secrecy, it is nothing compared to the lengths to which some academics go to shield their ideas from their own colleagues. So graceful is Bok under such pressures that the odd hesitation goes almost unnoticed. The Novartis Department of Plant and Microbial Biology - I beg your pardon, the University of California, Berkeley, Department of Plant and Microbial Biology and its \$25-million deal with Novartis - was "probably not a significant threat to academic values".

Bok is acutely sensitive to the complexities of institutional governance and to the incentives that drive individuals. He is less attuned to the cultural dynamic. Science and technology are no longer independent, the former to be undertaken for its own sake and the latter for profit. They have become symbiotic. Indeed, in some cases - quantum computing comes to mind - industry, not academia, has made the running. It is not profit-making that drives universities and companies to jostle on the intellectual commons; it is the jostling that drives the profit-making. As the example of quantum computing suggests, the pattern of interaction between academia and industry varies from discipline to discipline. If the biosciences need lines drawn to prevent abuses, the physical and computational sciences need encouragement to foster more collaboration between academia and industry, not less.

As Bok points out, there is a long history of gloomy prophecies about the decline of the university. None of these have come to pass. Here too there is a powerful dynamic at work. The intellectual life is a vocation, and the university has become its only real haven. If some academics and universities make frightful blunders, others will learn from them - as many will do from this thoughtful and thought-provoking book.

Jeremy Gunawardena is at the Bauer Centre for Genomics Research, Harvard University, Cambridge, Massachusetts 02139, USA.

\section{More on US universities}

Who's in Charge of America's Research Universities? A Blueprint for Reform by Thomas J. Tighe

State University of New York Press, $\$ 59.50$ ( $h b k$ ), $19.95(p b k)$ 